УДК: $72.033 ; 82(091)$

ББК: 63.3(0)4; 83.3(0)4; 85.11

A43

DOI: $10.18688 /$ aa199-2-19

F. Vitto

\title{
Wall Decoration of Early Byzantine Churches and Synagogues in the Eastern Mediterranean
}

In comparison with contemporaneous churches of the Western Roman Empire, very few remains of wall decoration have been preserved in situ in the Early Byzantine churches of the Eastern Mediterranean. Many walls of these churches have collapsed over the years, and knowledge of their interior decoration is mostly restricted to their pavements which were often decorated with nice polychrome mosaics, thus giving a misleading impression that floor mosaics constituted the primary decoration of their interior.

One reason for the difference between the Christian East and West is that in towns like Ravenna, Milan or Rome, several $5^{\text {th }}$ and $6^{\text {th }}$ century A.D. churches continued to be used, almost without interruption, until today, while in Palestine, Phoenicia and Arabia (presentday Israel, Lebanon and Jordan), most churches were abandoned in the centuries following the Muslim conquest, and they fell into decay.

Nevertheless, a relatively good idea of the mural decoration of the churches of the Christian East may be formed thanks to portions of patristic literature mentioning this décor, remains of wall decoration still in situ or collected in the debris covering the floors, as well as a few wall mosaics which have survived in the apses of churches in the Sinai, eastern Turkey and Cyprus [16; 22, p. 284, fig. 7; 35, pp. 73-76].

Descriptions of wall mosaics and paintings which adorned Palestinian and Syrian churches appear in the writings of Early Church Fathers. They speak of the splendid paintings and mosaics that adorned the walls of the churches, calling them "golden mosaics", a hint at the use of gilded tesserae. They describe the "beautiful paintings" which were on the walls of several churches in Jerusalem, the Church of the Ascension on Mount of Olives and the Church of the Anastasis (Holy Sepulchre). On Mount Zion, a representation of the Last Supper is said to have appeared on the dome of the chamber where it took place. The hospitality of Abraham was painted on the walls of the Basilica of Mamre [2, pp. 231-232; 32, pp. 62, 71-72; 53, pp. 286-287]. A conciliar epistle of A.D. 836 even attributes a miracle to a mosaic adorning the façade of the Church of the Nativity in Bethlehem, which represented the Nativity of Jesus with the "Mother of God holding the infant Jesus and the adoration of the gift-bearing Magi". In A.D. 614, when the army of the Persian king Khusraw II was invading the Holy Land, burning and plundering churches on their way, the sight of the Magi in Persian dress is said to have induced the Persians to spare the church. Several pilgrims, Epiphanius the Monk of Constantinople, Jacinthus the Priest and Eutychius of Alexandria, who visited the Bethlehem Church and Manger after the Persian and Muslim invasions, still describe the golden mosaics and the 
paintings displaying images of the Nativity and the Adoration of the Magi. Today, mainly because of the mosaics and paintings which were added on the walls in the $12^{\text {th }}$ century, nothing of the original decoration has survived [2, p. 234; 4, pp. 91-95; 32, p. 114].

The most detailed account of wall decoration appears in early $6^{\text {th }}$-century orations delivered by Choricius of Gaza at inauguration ceremonies for two churches of Gaza, the Church of St. Sergius and the Church of St. Stephen, in honour of the founder, Bishop Marcianus [32, pp. 60-72; 41; 42]. In his ekphrasis for the Church of St. Sergius, Choricius describes the "gilded and silver wall mosaics" representing the Virgin and Child with, to her right, Stephen, governor of Palestine, offering the church to St. Sergius. In the side apses were vine scrolls sprouting from an amphora and containing birds. The walls of the nave were adorned with paintings representing cycles from the life of Jesus, his birth and childhood, his miracles starting with the wedding of Cana and ending with the raising of Lazarus from the dead, and finally the Passion. For the Church of St. Stephen, on the triumphal arch, two standing figures were flanking Christ, St. Stephen and the founder, Bishop Marcian. On the walls of the nave, a Nilotic scene represented the Nile River with meadows and water birds along its banks.

Greek inscriptions on mosaic floors of Early Byzantine churches also give some information about the wall decoration of these churches. An inscription dated to A.D. 573/4, which appears in a church at el-Rashidiyah/al-Tafila, hints at the presence of a picture of the Virgin with Child in the apse of the church: "Entering here you will see the Virgin Mother of Christ, the ineffable Logos, dispensation of God. And if you believe, you will be saved" [12, pp. 587-592, fig. 7; 31, pp. 10-11, figs. 7-8]. A similar representation is suggested by an inscription in the Church of the Virgin at Madaba: "If you want to look at the Virgin Mary, Mother of God, and to Christ to whom she gave birth, only Son of the only God, purify your mind, flesh and works" [9, pp. 52-55; 11; 38; 40, pp. 64-65].

The earliest-known example of wall paintings which have been preserved in a Christian building is the pre-Constantinian, mid- $3^{\text {rd }}$ century A.D., Dura Europos baptistery, located at the eastern edge of the Roman Empire, in modern-day Syria, near the border with Iraq [25; 37]. Its walls represent scenes from the Bible and the Gospels painted in vivid colours, such as Adam and Eve, David and Goliath, the Good Shepherd, the Healing of the Paralytic, Jesus and Peter walking on the water and the Three Women at Jesus' tomb. Because of their early date and their location, far away from the Holy Land, caution is called for when trying to surmise from these paintings what the wall decoration of the Early Byzantine churches of the Eastern Mediterranean may have been, two or three centuries later.

The main remains of wall decoration which have survived in these churches are the following:

In Cyprus, mosaic representations of the Theotokos have been preserved in situ in the apse of the churches at Kiti, Livadia and Lynthrankomi [35, pp. 73-76].

In the early $6^{\text {th }}$-century Monastery of Mar Samuel, Mar Simeon and Mar Gabriel near Kartmin, in south-eastern Turkey, a mosaic representing a vine trellis issuing from amphorae has been preserved on the vault [22, p. 284, fig. 7].

In the late $5^{\text {th }}$ century Church of St. Theodore in Gerasa/Jerash, a fragment of wall mosaic representing a guilloche was found adhering to a voussoir of the nave arcade [23, p. 313, pl. XXXVIIId]. 


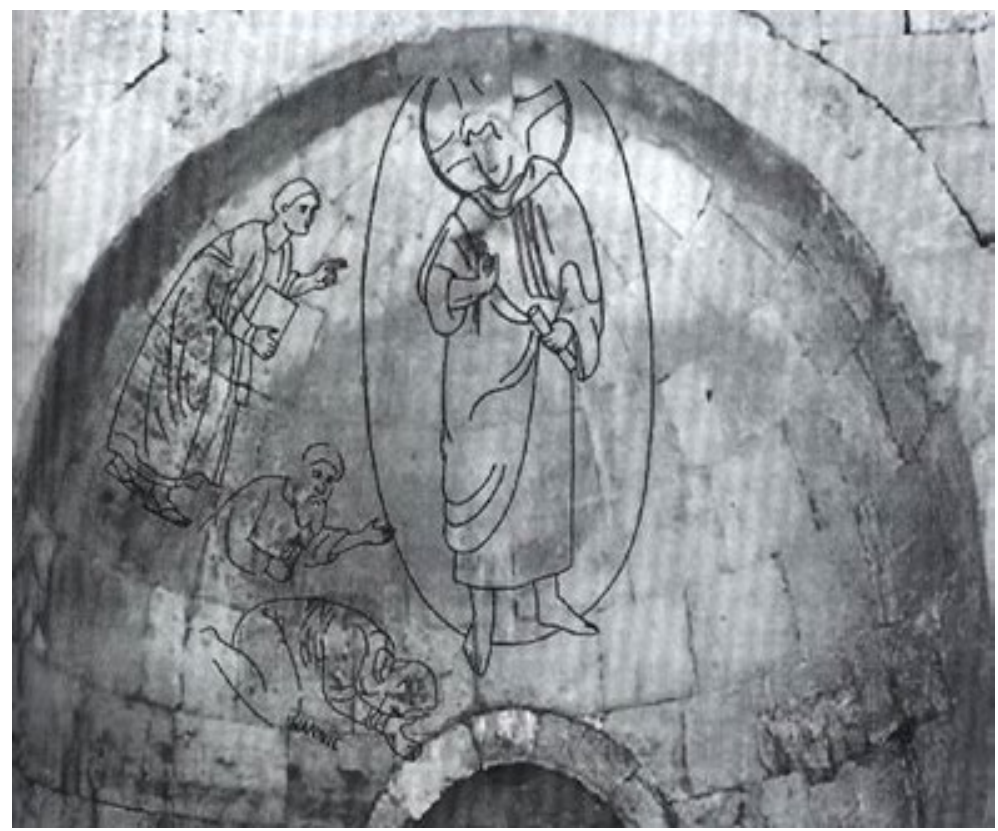

Fig. 1. Transfiguration. The church at Shivta. Drawing by Fanny Vitto after P. Figueras 2006-2007 [15]

In a $5^{\text {th }}-6^{\text {th }}$-century church at Petra, several fragments of wall mosaics were discovered in the debris, mostly in the apse area. Among those which could be identified are fruits, plants, as well as a few human faces which may have belonged to scenes representing Mary, Jesus and saints [56].

The best preserved examples of wall mosaics and paintings of the Christian East are in the church of the Monastery of Saint Catherine in the Sinai, built in the mid- $6^{\text {th }}$ century by the emperor Justinian (Ill. 27). In the apse of this church is a wall mosaic representing, on a golden background, the Transfiguration on Mount Tabor with, in the centre, Jesus with a cruciform halo within a blue mandorla. He is flanked by Elijah and Moses, standing above his disciples John and James who are kneeling and Peter who is lying on the ground. Surrounding the central scene are medallions of busts of apostles, evangelists and prophets. The medallion above Jesus contains a golden cross, and the one below him, the bust of David, his royal ancestor, represented as a Byzantine emperor without a beard, probably alluding to Justinian, the founder of the monastery. Above the arch are two flying angels offering a sceptre and an orb to the Lamb of God in the centre. Below the angels are two medallions with the busts of John the Baptist and the Virgin, symbolising the Deisis. The uppermost area is occupied by two scenes of the life of Moses, to the left Moses removing his sandals in front of the Burning Bush, and to the right Moses receiving the Tablets of the Law in the form of a parchment roll, both scenes which, according to tradition, happened at this very spot. Wall paintings dating to the $6^{\text {th }}$ and $7^{\text {th }}$ centuries have also been preserved in this church. A fresco imitating marble revetment is preserved on the south wall, and a design simulating a coffered ceiling, with rosettes and birds in the coffers, adorns a vault. On either side of the apse of the church, two panels, painted in 


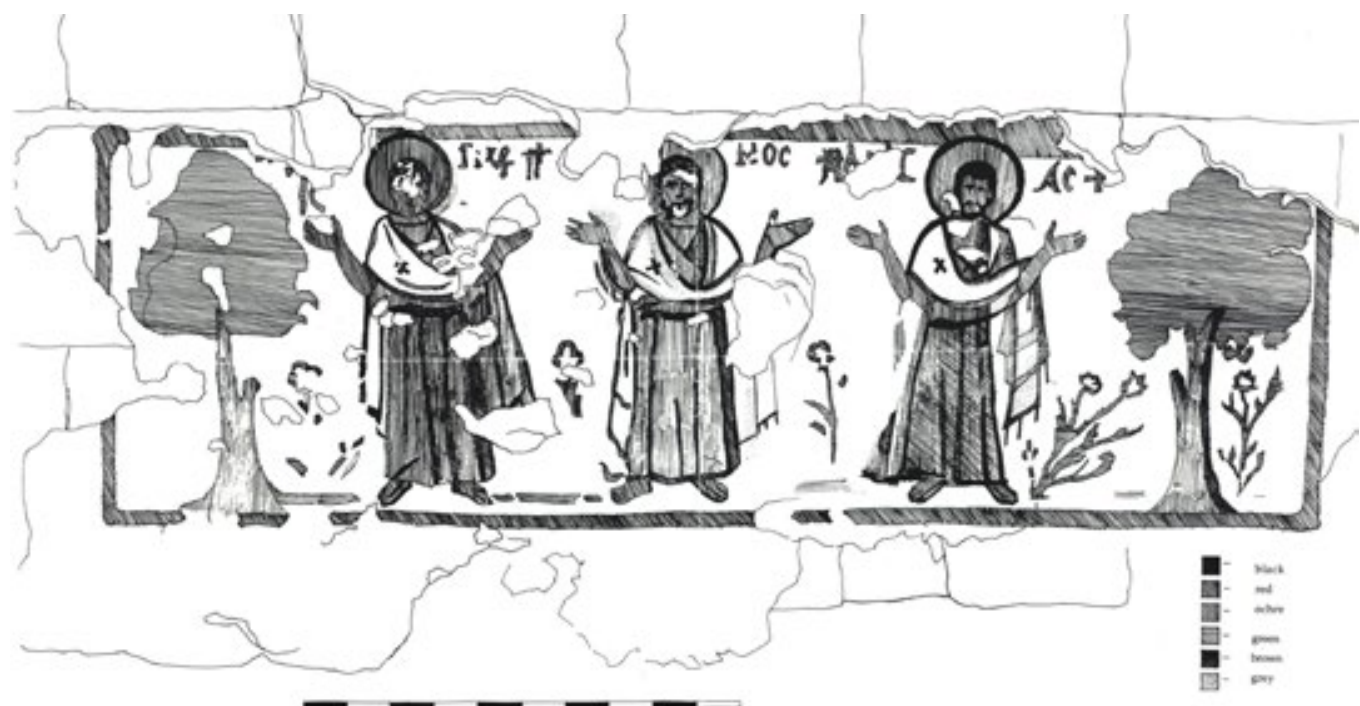

Fig. 2. Panel representing three saints. Caesarea Maritima. Drawing by Fanny Vitto after T. Avner [3]

encaustic technique on marble, represent the Sacrifice of Isaac and the Sacrifice of Jephtha's daughter, a scene unique in Early Christian art [16; 40, p. 334, fig. 714].

A Transfiguration was also represented in the $6^{\text {th }}$ century southern church at Shivta/Sobota in the Negev but as a wall painting (Fig. 1). Remains of painted plaster are still visible in the northern and central apses but they are too faint to know what was represented. In the southern apse, the painting has better survived and was first described and identified in 1914 by C. L. Woolley and T. E. Lawrence (Lawrence of Arabia). In the centre is Jesus, haloed, wearing a long tunica and a toga within a mandorla. To the left (to Jesus' right), three figures are represented, Elijah (or Moses) standing above Peter, kneeling, recognisable by his beard, and beneath, John, prostrate, identified by the last five Greek letters of his name. To the right was Moses (or Elijah), standing above James, probably kneeling [15; 27; 57, pp. 89-90]. Faint remains of a wall painting are also visible in the apse of the baptistery of the northern church at Shivta, above a cruciform baptismal font. Two haloed figures are visible, the one in the centre has a youthful, beardless face with short hair, and the figure to the left is bent towards him, his arm raised in his direction. In light of the function of the building, this painting has generally been identified as a baptism scene, with Jesus in the middle and John the Baptist to his right [28; 49, pp. 590-591, fig. 6]. At another site in the Negev desert, Rehovot-in-the-Negev, many remnants of plaster with Greek inscriptions were found together with a human face, probably a saint holding a scroll [50, pp. 65-67, ill. 94].

At Umm al-Rasas, in the Church of the Priest Wa'il dating to the end of the $6^{\text {th }}$ century, remains of painted decoration were found still adhering to the voussoir of an arch, clearly originating in the apse. They represent a male figure with a beard and halo, sitting and holding an open book, a representation of a saint or of Christ enthroned. Next to him are circles containing birds and plants. Another fragment shows a net of lozenges containing a cross, a vase and leaves $[1 ; 39$, pp. 317-318, figs. 12-14]. 
In Caesarea Maritima, two large panels painted with figural representations, enclosed in rectangular red frames, were discovered in situ on the walls of vaulted rooms of unclear function. One of the panels contains three standing saints represented in an orans gesture, with an ochre halo simulating gold (Fig. 2). They wear a long, black-girdled, ochre dress, and on it, a white stole with a small cross. The saints are flanked by a leafy tree on each side. Red flowers are inserted between the saints and on either side of the trees. Above each saint is a Greek caption, only part of one is visible, Ioannis (John). The other panel contains thirteen nimbate figures arranged frontally in a row, representing Christ with a short beard in the middle, flanked by the twelve apostles, six on either side. Christ is slightly elevated above the others and has a cruciform halo, larger than the others. To the right is Peter holding a cross, and to the left Paul. Beneath the frame of the panel, a Greek inscription in red paint opens with a small cross and runs along the entire panel. It consists of three parts separated by a tilde. Because of its poor preservation, its meaning is unclear, "...they believed in these things, saving... animals". Since all the faces of the apostles are turned to the centre and the apostles point their hands at Christ, the scene has been explained as the Acclamation of Christ by the apostles in the heavenly kingdom. Based on stylistic and epigraphic grounds, the two panels have been dated to the late $6^{\text {th }}$ or early $7^{\text {th }}$ century $[3 ; 26$, p. 116 , no. 113 , pls. LXXVIII-LXXIX].

The debris of many churches have yielded loose glass and gilded tesserae, most probably fallen from wall mosaics in the apse area, as well as fragments of painted plaster, generally too small or too faint to allow a reconstruction of their decorative scheme. They indicate that many more churches were decorated with wall mosaics or paintings, or both. For instance, glass and gilded tesserae were discovered in churches at Shavei Zion, Ashkelon, Sussita-Hippos, Beth Shean, Mount Gerizim, St. Anne in Jerusalem, Mount Nebo [53, p. 288], Khirbet Makkus [17, p. 334], Pella [34, p. 160], Abila and Gerasa, [36, p. 41], and small remains of wall paintings were found in churches at Sussita-Hippos, Shavei Zion, Ras et-Tawil near Jerusalerm, Bethlehem, Nizzana, Avdat, Mamshit-Kurnub [53, p. 289], Megiddo [48, p. 26], Pella [34, p. 160], Maale Adummim [29, p. 182], Khirbet ed-Deir, Khirbet el-Quneitra [7], Horvat Karkur [14, pp. 140-147], Petra [56, p. 333, nos. 309-314], Gerasa, Umm al-Rasas, Mount Nebo and Yasilah [36, p. 41].

Concerning the synagogues, we know next to nothing from written sources about their wall decoration. Many of the synagogues were paved with polychrome mosaics, displaying a wide range of motifs: vine scrolls filled with animals and birds, the zodiac wheel, biblical scenes, but also Jewish religious motifs such as the Torah shrine, the menorah and other ritual objects [21; 45 ; 47]. In Rabbinic literature, there is only one passage which refers to wall decoration, without giving any indication of what may have been represented: "In the days of Rabbi Yohanan, they began to make drawings on the walls and he did not prevent them" (Palestinian Talmud, Tractate Avodah zarah 3:3). The wording of this text suggests that the $3^{\text {rd }}$-century A.D. sage, who was a native of Sepphoris and founder of the academy of Tiberias, grudgingly accepted such decoration even though he was generally known for his lenient rulings [6, p. 198].

A mosaic floor inscription in Hebrew script, uncovered in the courtyard of the synagogue at Susiya, merely indicates that the walls of the synagogue were plastered, without specifying if this plaster was decorated: "Rabbi Isai the priest who made this mosaic and plastered the walls with lime which he donated at a feast" [18, pp. 127-128]. 
Ever since the discovery in 1932 of the mid- $3^{\text {rd }}$ century A.D. synagogue at Dura-Europos, located at the eastern extremity of present-day Syria on the Euphrates River, with its wall paintings representing a wide array of biblical scenes, archaeologists have been hoping to uncover similar remains in the synagogues of the Holy Land [19; 24]. So far, nothing even slightly similar has been found in Palestinian synagogues. Even if the exceptionally good preservation of the Dura wall paintings is due to the fact that the synagogue was used only for a short period - maximum twelve years - and was completely buried as a defensive measure during the Sassanian siege in A.D. 256, it is highly improbable that similar paintings will ever be found in Palestinian synagogues. Indeed, the Dura paintings belong to different cultural and artistic realms and their exceptional richness is in part to be explained by the fact that this frontier garrison city was an ethnic melting pot, with buildings belonging to a whole range of faiths, including a synagogue, a Christian building (domus ecclesia and baptistery), a Mithraeum, and sixteen temples variously dedicated to Greek, Roman and Palmyrene gods.

No evidence of wall mosaics has been found in Palestinian synagogue, however, several discoveries have shown that their inner walls and columns were usually covered with plaster. In many cases, this plaster bore remains of painting, chiefly red, but other pigments were also used such as pink, black, yellow and green. Most fragments found in the debris are too small to guess what was represented. Among the synagogues where white or unidentifiable painted fragments of plaster have been found are those at Huseifa, Summaka, Khirbet Shema, Beth Shearim, Hammat Gader, Meroth, Assalieh, Qasrin, Korazin, Magdala, Horvat Kur, Maoz Haim, Beth Alpha, Umm al Umdan near Modiin, En Gedi and Rimon [21, pp. 249-250; 46, pp. 98-99; 53, pp. 292-293].

In a number of cases, it was possible to form an idea of the motif represented. At Hammath Tiberias, red bands as well as volutes and an egg-and-dart motif in red paint were visible, and in the synagogue of Beth Alpha, "simple designs of flowers in red were perceptible" [13, p. 22, pls. $23: 1-2,36: 1,3 ; 44$, pp. 12,$14 ; 53$, p. 293]. In the early $5^{\text {th }}$-century synagogue at Huqoq, where the mosaic floor is decorated with an exceptionally rich array of biblical and historical scenes, a few fragments of painted plaster were found still adhering to columns while others were collected in the debris. They belong to two layers of plaster and represent, in red, yellow, orange and pink paint, geometric and vegetal motifs, including vine or ivy leaves [39, pp. 74, 84, fig. 22, 88, 91, fig. 29].

In two synagogues, archaeologists mention (without illustrating them) tiny fragments of plaster with very fragmentary remains of inscriptions in Hebrew script, in red paint. In the synagogue at En Gedi, near the Dead Sea, it reads "himself", and in the mid- $5^{\text {th }}$ century synagogue at Ein Nashut in the Golan Heights, "Amen sela shalom" (a term often found at the end of inscriptions). They were apparently parts of dedicatory texts with names of donors [5, p. 39*; 33, p. 32].

The synagogue of Rehov in the Beth Shean Valley, excavated by the author, yielded exceptionally rich evidence concerning the revetment of its walls and columns. Although most walls were found razed to floor level, the debris covering the floor contained a very large quantity of painted plaster bearing a few decorative elements and, mainly, Aramaic inscriptions in Hebrew script. They belong to two layers of plaster and the paint of the lower layer, which dates to the $5^{\text {th }}$ century A.D., was preserved thanks to the second layer which had been applied on top of 
the first layer [53, pp. 293-296; 55]. The walls of the synagogue were mainly decorated with wide red stripes against a white background. Fragments of plaster discovered near the side entrance of the synagogue, probably fallen from the ceiling, feature a green grid containing red quatrefoils, imitating a coffered ceiling (Ill. 28). One fragment found near its main entrance represents, in red paint on a white background, the anterior part of a large fish whose total length can be estimated as seventy-five centimetres. Its mouth is open, showing sharp pointed teeth, and its dorsal fin consists of spiny rays. It is not possible to know to which scene this fish may have belonged: a Nilotic landscape, a marine scene, or perhaps a biblical scene, such as the scene representing pharaoh's soldiers drowning in the Red Sea and swallowed by large fish (Exodus 14:27-28), which appears on the floor mosaics of the synagogues of Huqoq and Wadi Hamam [30, pp. 102-106], or the scene of Jonah (Jonah 2:1-11), swallowed and then spit out three days later by a large fish [54]. Whatever the scene to which it belonged, it would be the first known example in a Palestinian synagogue of a wall painting which is not geometric or vegetal.

Most of the plaster recovered during the excavation in the Rehov synagogue came from the original coating of the pillars separating the nave from the aisles. On each pillar was a large wreath containing mainly Aramaic and Hebrew inscriptions in red paint. One wreath contains, within a tabula ansata, a long dedicatory inscription, with a list of names of donors (Ill. 29). Another long inscription deals with the laws pertaining to the tithes and produced in the various regions of the country. The Beth Shean region, where the synagogue is located, appears first and includes the names of the city gates. Other inscriptions contain a list of the annual fast days, a list of the priestly courses serving in the Temple, as well as references to events in the life of the congregation. One wreath, originally located on a pillar near the bema, encloses a drawing of a Torah shrine with a seven-branched menorah.

\section{Conclusion}

Despite the scarcity of evidence for wall decoration in the Early Byzantine churches and synagogues of the Eastern Mediterranean, it is possible to discern significant differences between the two.

The main reason is a difference of attitudes of the two religions towards images. In Judaism, the prohibition against images in the Second Commandment of the Decalogue (Exodus 20:4-6; Deuteronomy 5:8-9) was strictly observed in the Second Temple period and during the century following the destruction of the Temple in A.D. 70. Even at Dura Europos, the early synagogue, built in the $2^{\text {nd }}$ century A.D., prior to the great renovations of A.D. 244 when all the paintings were added, was a conventional and plain building, decorated with exclusively geometric motifs. In the $3^{\text {rd }}$ century, rabbinic texts started to discuss the permissibility of visual art for Jews $[6 ; 51]$. From the $4^{\text {th }}$ century onwards, the prohibition of making images was less strictly applied, and Jewish religious motifs, biblical scene or other figural representation, including the zodiac with Helios in the centre, began to be depicted on the mosaic floors of the Palestinian synagogues. Some scholars claimed that the liberal interpretation of the Second Commandment was a result of the weakening of paganism. In fact, the flourishing of Jewish art under Byzantine rule was mainly a response to the use of art in Christianity to promote its faith.

Some Jewish sages vehemently opposed any artistic reference to Graeco-Roman motifs and disapproved of money spent beautifying synagogues instead of supporting needy 
scholars (Jerusalem Talmud, Tractate Sheqalim 49b) [6, pp. 202-203]. However, the rabbinic apprehension was mainly towards potentially idolatrous images. This is evidenced by a text of the Targum Pseudo-Jonathan that reads: "A figured stone you shall not place in your land to bow down upon it. However, a stoa (a mosaic floor) decorated with figures and likenesses, you may put on the floor of your sanctuaries (synagogues), but not to prostrate yourselves on it" [6, p. 197]. The Second Commandment was now understood not anymore as a prohibition to represent images but as a prohibition to treat them as idols. This is why, in synagogues, human and animal representations appear on the floors and not on the walls. The fact that these mosaics could be trodden upon ensured that no ritual worship of the image would develop. By contrast, in the churches, mosaics on which one could walk were considered unfitting for the depiction of human figures from the Holy Scriptures and for sacred motifs such as the cross and these should appear on the walls. After the edict issued in A.D. 427 by Theodosius II and Valentinianus II, prohibiting the inclusion of the Signum Christi in the floor, few mosaic floors feature the cross, and when they do, the crosses are generally located where they would not be trodden on, for instance under the altar. Narrative scenes from the Old and New Testaments are almost totally absent from mosaic floors of churches which represent rural and hunting scenes, inhabited scrolls and Nilotic landscapes. The question whether these scenes, and in particular the Nilotic landscape, carried an allegorical meaning or were purely decorative, has been extensively debated by scholars [46, pp. 182-183].

Patristic literature shows that the attitude of the Church Fathers was not uniform. Various written sources, mainly the emperor's letters, indicate that Constantine wished that the churches be large and richly decorated. The best craftsmen should be employed and they should use generously precious materials, coloured marble, bronze and gold for these structures are meant to reflect the glory of Christ. However, several Church Fathers, such as Epiphanius of Salamis in the $4^{\text {th }}$ century and Theodotus of Ancyra in the $5^{\text {th }}$ century, were opposed to representations which were purely decorative scenes. They were in favour of art as a means of education, especially for those who were illiterate. Gregory of Nyssa (A.D. 335-395) was favourable to pictorial representations in churches so that those who "are illiterate may at least read by looking at the walls what they cannot read in books". Evagrius (A.D. 345-349) wrote about a fresco at Apamea: "An image [of the miracle] was set up in the ceiling of the church to make known these events by means of painting to those who were ignorant of them". In a $5^{\text {th }}$-century Letter to Prefect Olympiodorus, Saint Nilus of Sinai (d. A.D. 430) expressed his hostile attitude towards hunting and fishing genre scenes in churches, which, in his opinion, "distract the eyes of the faithful". He recommended representing a large cross in the apse of the church and on the walls "pictures from the Old and New Testament, so that the illiterate who are unable to read the Holy Scriptures, by gazing at the pictures, may become mindful of the manly deeds of those who have genuinely served the true God, and may be roused to emulate those glorious and celebrated feats" [10, p. 180, n. 79; 32, pp. 4-7, 10-14, 32-37].

These texts suggest that many of the early Christians were not able to read the Scriptures themselves. On the other hand, most members of the Jewish congregation, at least the male members, were literate since they were used to reading and studying the Holy Scriptures. The inscriptions of the Rehov synagogue indicate that the walls and columns of the synagogue chiefly served to inform the members of the local congregation of matters of primary concern 
to them, whether connected with daily life or religious activities. The function of the synagogue was not only the reading and studying of the Hebrew Bible but also a communal home where the local inhabitants were meeting to share various Jewish traditions. Synagogue services were primarily attended by a local and long-established population while the church liturgy was attended by a body of worshippers still in the making, mostly former pagans who were used to temples containing statues and images of gods. The lavish decoration of churches was intended to elicit the admiration of worshippers and pilgrims alike, and every effort was made to attract new converts. Under Byzantine rule, the Church enjoyed a much better economic situation compared to that of the local Jewish population, and, as a result, the wall decoration of the churches consisted of mosaics and paintings, often made by skilled artists, while in synagogues, there were no wall mosaics, only floor mosaics, and a few simple wall paintings made by local artists.

The attitude of the Church towards images changed in the $8^{\text {th }}$ century. In the $6^{\text {th }}$ and $7^{\text {th }}$ centuries, the veneration of icons of Jesus, the Virgin, saints and martyrs had become increasingly pronounced. As a result, in the early $8^{\text {th }}$ century, a number of Anatolian bishops campaigned against the veneration of images. Several imperial edicts and church councils condemned icon worship as diabolical, and images of Christ, the Virgin and the saints were destroyed. In the Holy Land, however, there is no literary evidence supporting the deliberate destruction of sacred images, and some Christians, like John of Damascus (A.D. 675-749), remained in favour of images. While in many churches, human and animal figures were defaced, often leaving the shape of what was destroyed, other churches, mainly in Transjordan, built or renovated in the $8^{\text {th }}$ century, continued to represent until the 760s figurative motifs on their mosaic floors, side by side with geometric motifs. Incidentally, synagogues dating to the late $7^{\text {th }}$ and $8^{\text {th }}$ centuries show a return to aniconism and a preference for geometric mosaic floors. Many scholars attribute the defacement of figures to the iconoclastic edict issued by the Umayyad Caliph Yazid II in A.D. 721, while others ascribe it to an edict allegedly issued by the Byzantine emperor Leo III in A.D. 726. No single explanation may account for the return to a non-figurative art and the defacement of figurative motives in religious buildings of both faiths. The picture is more complex, the result of several events and factors [8, pp. 69-155; 20; 43; 52].

\section{References}

1. Acconci A. Su alcuni laterci pittorici di Umm er-Rasas-Kastron Mefaa. Barsanti C.; Acconci A.(eds.). Bisanzio e l'Occidente: Arte, archeologia, storia. Studi in onore di Fernanda de' Maffei. Rome, Viella Publ., 1996, pp. 193-201 (in Italian).

2. Ainalov D. V. The Hellenistic Origins of Byzantine Art. New Brunswick, Rutgers University Press Publ., $1961.322 \mathrm{p}$.

3. Avner T. Early Byzantine Wall-Painting from Caesarea. Holum K. G.; Raban A.; Patrich J. (eds.). Caesarea Papers 2: Herod's Temple, the Provincial Governor's Praetorium and Granaries, the Later Harbor, a Gold Coin Hoard, and Other Studies (Journal of Roman Archaeology Suppl. S. 35). Portsmouth, Journal of Roman Archaeology Publ., 1999, pp. 108-128.

4. Bacci M. The Mystic Cave: A History of the Nativity Church in Bethlehen. Brno, Masaryk University Publ.; Rome, Viella Publ., 2017. 316 p.

5. Barag D. The Synagogue at Ein Gedi. Hirschfeld Y. (ed.). Ein Gedi: "A Very Large Village of Jews" (Hecht Museum Catalogue 25). Haifa, Hecht Museum Publ., 2006, pp. $17^{\star}-20^{\star}$.

6. Baumgarten J. M. Art in the Synagogue: Some Talmudic Views. Judaism, 1970, vol. 19, pp. 196-206. 
7. Ben-Arieh R. The Frescoes. Hirschfeld Y. (ed.). The Early Byzantine Monastery at Khirbet ed-Deir in the Judean Desert: The Excavations in 1981-1987 (Qedem 38). Jerusalem, Hebrew University of Jerusalem Publ., 1999, pp. 133-134.

8. Brubaker L.; Haldon J. Byzantium in the Iconoclast Era c. 680-850: A History. Cambridge, Cambridge University Press Publ., 2011. 918 p.

9. Clermont-Ganneau C. La mosaïque de Medaba. Recueil d'archéologie orientale II. Paris, Ernest Leroux Publ., 1898. 422 p. (in French).

10. Deines R. God's Revelation through Torah, Creation, and History: Interpreting the Zodiac Mosaics in Synagogues. Leibner U.; Hezser C. (eds.). Jewish Art in Its Late Antique, Context (Texts and Studies in Ancient Judaism 163). Tübingen, Mohr Siebeck Publ., 2016, pp. 155-186.

11. Di Segni L. The Date of the Church of the Virgin in Madaba. Liber Annuus, 1992, vol. 42, pp. 251-257.

12. Di Segni L. Varia Arabica. Liber Annuus, 2006, vol. 56, pp. 578-592.

13. Dothan M. Hammath Tiberias: Early Synagogues and the Hellenistic and Roman Remains. Jerusalem, Israel Exploration Society Publ., 1983. 88 p.

14. Figueras P. (ed.). Horvat Karkur 'Illit: A Byzantine Cemetery Church in the Northern Negev; Final Report of the Excavations 1989-1995 (Beer-Sheva XVI). Be'er-Sheva', Ben-Gurion University of the Negev Press Publ., 2004. 359 p.

15. Figueras P. Remains of a Mural Painting of the Transfigration in the Southern Church of Sobata (Shivta). Aram, 2006-2007, vols. 18-19, pp. 127-151.

16. Forsyth G. H.; Weitzmann K. The Monastery of Saint Catherine at Mount Sinai: The Church and Fortress of Justinian. Ann Arbor, University of Michigan Press Publ., 1965. 20 p.

17. Gibson S.; Vitto F.; Di Segni L. An Unknown Church with Inscriptions from the Byzantine Period in Khirbet Makkus near Julis. Liber Annuus, 1998, vol. 48, pp. 315-334.

18. Gutman S.; Yeivin Z.; Netzer E. Excavations in the Synagogue at Horvat Susiya. Levine L. I. (ed.). Ancient Synagogues Revealed. Jerusalem, The Israel Exploration Society Publ., 1981, pp. 123-128.

19. Gutmann J. The Dura-Europos Synagogue: A Re-evaluation (1932-1972) (Religion and the Arts 1). Missoula, American Academy of Religion Publ., 1973. 190 p.

20. Habas L. Destruction of Symbols and Iconoclasm after the Muslim Conquest. Aram, 2016, vol. 28, pp. 121-156.

21. Hachlili R. Ancient Synagogues - Archaeology and Art: New Discoveries and Current Research (Handbook of Oriental Studies 1; Ancient Near East 105). Leiden, Brill Publ., 2013. 738 p.

22. Hawkins J. W.; Mundell M. C.; Mango C. The Mosaics of the Monastery of Mar Samuel, Mar Simeon and Mar Gabriel near Kartmin. Dumbarton Oaks Papers, 1973, vol. 27, pp. 279-296.

23. Kraeling C. H. Gerasa: City of the Decapolis. New Haven, American School of Oriental Research Publ., 1938. $616 \mathrm{p}$.

24. Kraeling C. H. The Synagogue (Excavations at Dura-Europos 8/1). New Haven, Yale University Press Publ., 1956. 402 p.

25. Kraeling C. H. The Christian Building (Excavations at Dura Europos 8/2). New Haven, Dura-Europos Publ., 1967. 233 p.

26. Lehmann C. M.; Holum K. G. The Greek and Latin Inscriptions of Caesarea Maritima (Joint Expedition to Caesarea Maritima Excavation Reports 5). Boston, Oriental Schools of Oriental Research Publ., 2000. 292 p.

27. Maayan-Fanar E. The Transfiguration at Shivta: Retracing Early Byzantine Iconography. Zograf, 2017, vol. 41, pp. 1-18.

28. Maayan-Fanar E.; Linn R.; Tepper Y.; Bar-Oz G. Christ's Face Revealed at Shivta: An Early Byzantine Wall Painting in the Desert of the Holy Land. Antiquity, 2018, vol. 92/363. Available at: https://www. cambridge.org/core/journals/antiquity/article/christs-face-revealed-at-shivta-an-early-byzantine-wallpainting-in-the-desert-of-the-holy-land/1D3584D4866168E6764035D5DE740781/core-reader （accessed 20 March 2019).

29. Magen Y. The Monastery of St. Martyrius Máale Adumim. Tsafrir Y. (ed.). Ancient Churches Revealed. Jerusalem, Israel Exploration Society Publ., 1993, pp. 170-197.

30. Magness J. et al. The Huqoq Excavation Project: 2014-2017 Interim Report. Bulletin of the American Schools of Oriental Research, 2018, vol. 380, pp. 61-131.

31. Mahamid H. Results of the Excavation of the Church of al-Rashidiya/al-Tafila. Annual of the Department of Antiquities of Jordan, 2003, vol. 47, pp. 7-16 (in Arabic).

32. Mango C. The Art of the Byzantine Empire 312-1453: Sources and Documents. Englewood Cliffs; New Jersey, Prentice-Hall Publ., 1972. 272 p. 
33. Ma'oz, Z. U. 'En Nashut: The Art and Architecture of a Synagogue in the Golan (Archaostyle Scientific Research Series 7). Qazrin, Archaostyle Publ., 2010. 203 p.

34. McNicoll A. W. Pella in Jordan 2: The Second Interim Report of the Joint University of Sydney and College of Wooster Excavations at Pella 1982-1985 (Mediterranean Archaeology Supplement 2). Sydney, Meditarch Publ., 1992. 315 p.

35. Megaw A. H. S. Byzantine Architecture and Decoration in Cyprus: Metropolitan or Provincial. Dumbarton Oaks Papers, 1974, vol. 28, pp. 57-88.

36. Michel A. Les églises dépoque byzantine et umayyade de Jordanie : étude de typologie et inventaire (Bibliothèque de l'Antiquité tardive 2). Turnhout, Brepols Publ., 2001. 471 p. (in French).

37. Peppard M. Dura-Europos and the World Oldest Church. New Haven, Yale University Press, 2016. 320 p.

38. Piccirillo M. La Chiesa della Vergine a Madaba. Liber Annuus, 1982, vol. 32, pp. 373-408 (in Italian).

39. Piccirillo M. La Chiesa del Prete Wa'il a Umm al-Rasas-Kastron Mefaa in Giordana. Manns F.; Alliata E. (eds.). Early Christianity in Context: Monuments and Documents (Studium Biblicum Franciscanum Collectio Maior 38). Jerusalem, Franciscan Printing Press Publ., 1993, pp. 313-334 (in Italian).

40. Piccirillo M. The Mosaics of Jordan, Amman, American Center of Oriental Research Publ., 1993. 383 p.

41. Polański T. The Nilotic Mosaic in Saint Stephen's Church of Gaza in Choricius' Description. Studies in Ancient Art and Civilization, 2009, vol. 13, pp. 169-181.

42. Polański T. The Cycles of Childhood and Miracles in Saint Sergius' Church of Gaza in the Ecphrasis of Choricius. Dabrowa E. (ed.). Hortus Historiae: Studies in Honour of Professor Jozef Wolski on the $100^{\text {th }}$ Anniversary of His Birthday. Krakow, Historia Iagellonica Publ., 2010, pp. 737-760.

43. Schick R. The Christian Communities of Palestine from Byzantine to Islamic Rule: A Historical and Archaeological Study (Studies in Late Antiquity and Early Islam 2). Princeton, Darwin Press Publ., 1995. $583 \mathrm{p}$.

44. Sukenik E. L. The Ancient Synagogue of Beth-Alpha: An Account of the Excavations Conducted on Behalf of the Hebrew University, Jerusalem. Jerusalem, Hebrew University Press Publ., 1932. 58 p.

45. Talgam R. Mosaics of Faith: Floors of Pagans, Jews, Samaritans, Christians, and Muslims in the Holy Land. Jerusalem, Yad Ben-Zvi Press; University Park, Pennsylvania State University Press Publ., 2014. 579 p.

46. Talgam R. From Wall Paintings to Floor Mosaics: Jewish and Christian Attitudes to Figurative Art. Leibner U.; Hezser C. (eds.). Jewish Art in Its Late Antique Context (Texts and Studies in Ancient Judaism 163). Tübingen, Mohr Siebeck Publ., 2016, pp. 97-118.

47. Tchakovskaya L. S. Voploshchennaia pamiat' o Khrame: Khudozhesvennyi mir sinagog Sviatoi Zemli III-VI vv. N.E. (Figurative Memory of the Temple: The Artistic World of the Synagogues of the Holy Land, $3^{\text {rd }}-6^{\text {th }}$ Century A.D.). Moscow, Indrik Publ., 2011. 367 p. (in Russian).

48. Tepper Y.; Di Segni L. A Christian Prayer Hall of the Third Century CE at Kefar Othnay (Legio): Excavations at the Megiddo Prison 2005. Jerusalem, Israel Antiquities Authority Publ., 2006. 59 p.

49. Tonneau R. Chronique: Excursion biblique au Négeb. Revue Biblique, 1926, vol. 35, pp. 583-604 (in French).

50. Tsafrir Y. Excavations at Rehovot-in the-Negev I: The Northern Church (Qedem 25). Jerusalem, Hebrew University of Jerusalem Publ., 1988. 209 p.

51. Urbach E. E. The Rabbinical Laws of Idolatry in the Second and Third Centuries in the Light of Archaeological and Historical Facts. Israel Exploration Journal, 1959, vol. 9, pp. 149-165, 229-245.

52. Vasiliev A. A. The Iconoclastic Edict of the Caliph Yazid II, A.D. 721. Dumbarton Oaks Papers, 1956, vol. 9-10, pp. 23-47.

53. Vitto F. The Interior Decoration of Palestinian Churches and Synagogues. Efthymiadis S.; Rapp C.; Tsougarakis D. (eds.). Bosphorus: Essays in Honour of Cyril Mango (Byzantinische Forschungen 21). Amsterdam, Hakkert Publ., 1995, pp. 283-300.

54. Vitto F. Could the Biblical Story of Jonah and the Fish Appear in Jewish Art? The Fortieth Archaeological Conference in Israel, 10 April 2015, Haifa. Jerusalem, Israel Antiquities Authority Publ., 2014, p. 5 (in Hebrew).

55. Vitto F. Wall Paintings in the Synagogue of Rehov: An Account of Their Discovery. Israel Museum Studies in Archaeology, 2015, vol. 7, pp. 2-12.

56. Waliszewski T. The Wall Mosaics. Fiema Z. T. (ed.). The Petra Church. Amman, American Center of Oriental Research Publ., 2001, pp. 300-302.

57. Woolley C. L.; Lawrence T. E. The Wilderness of Zin (Palestine Exploration Fund Annual 3). London, Palestine Exploration Fund Publ., 1914-1915. 147 p. 
Title. Wall Decoration of Early Byzantine Churches and Synagogues in the Eastern Mediterranean.

Author. Fanny Vitto - field and research archaeologist. Israel Antiquities Authority, POB 586, Jerusalem 91004, Israel.vitfan1908@gmail.com

Abstract. Very few remains of wall decoration have been preserved in situ in the Early Byzantine churches and synagogues of the Eastern Mediterranean. Writings of Church Fathers contain descriptions of elaborate wall mosaics and paintings in churches of the Holy Land which make up to some extent for the dearth of material evidence. Concerning the synagogues, there is only a laconic allusion to wall decoration in the Jerusalem Talmud which does not give any indication of what may be represented.

Excavations of Palestinian churches have yielded evidence of both wall mosaics and polychrome wall paintings which represent mostly saints, the Virgin and scenes of the Transfiguration. In synagogues, the few preserved wall paintings consist of simple geometric and stylized plant motifs, as well as texts in Aramaic which are dedicatory in nature or connected with the service in the synagogue.

Despite the scarcity of evidence, it is possible to discern significant differences between wall decoration in churches and in synagogues. One of the reasons is the difference of attitudes of the two religions towards images, the prohibition of treading upon human figures of the Holy Scriptures in Christianity, and the prohibition of treating images as idols in Judaism. Another reason is the difference in the people who attended the religious services, a mostly local and long-established population in the synagogues whereas, in the churches, the body of worshippers was still in the making and the lavish decoration of the churches was intended to attract new converts and teach the Holy Scriptures to those who were illiterate.

Keywords: Holy Land; wall decoration; Early Byzantine churches; synagogues.

Название статьи. Монументальная декорация раннехристианских церквей и синагог в Восточном Средиземноморье.

Сведения об авторе. Витто Фанни - археолог. Израильское управление по делам древностей, РОВ 586, Иерусалим, Израиль, 91004; vitfan1908@gmail.com

Аннотация. От монументальной декорации церквей и синагог ранневизантийского периода в Восточном Средиземноморье сохранилось очень мало. В нескольких сочинениях Отцов Церкви содержатся описания прекрасных мозаик и росписей в церквах Святой земли, которые до некоторой степени компенсируют скудость материальных свидетельств. О настенной живописи в синагогах есть только одно краткое упоминание в Иерусалимском Талмуде, из которого невозможно понять, что именно могло быть изображено.

Раскопки в палестинских церквах выявили остатки настенных мозаик и полихромных росписей, на которых были изображены в основном святые, Богородица и сцены Преображения. В синагогах в немногих сохранившихся росписях представлены только простые геометрические и стилизованные растительные мотивы, а также тексты на арамейском языке, имеющие посвятительный характер или относящиеся к служению в синагоге.

Несмотря на скудость информации, можно проследить существенные различия в монументальной декорации церквей и синагог. Одна из причин различий в оформлении стен в церквах и синагогах - разное отношение двух религий к образу. В христианстве существовал запрет наступать на изображения сюжетов из Священного Писания, в иудаизме - почитать изображения как идолов. Другая причина состояла в различии в материальном положении и в составе людей, участвовавших в обрядах. В синагогах это было в основном местное население, давно проживающее на данных территориях, тогда как христианские общины находились еще в процессе формирования, и роскошное украшение церквей способствовало привлечению в них новых членов и делало доступным Священное Писание неграмотным.

Ключевые слова: Святая Земля; настенная декорация; ранневизантийские церкви; синагоги. 


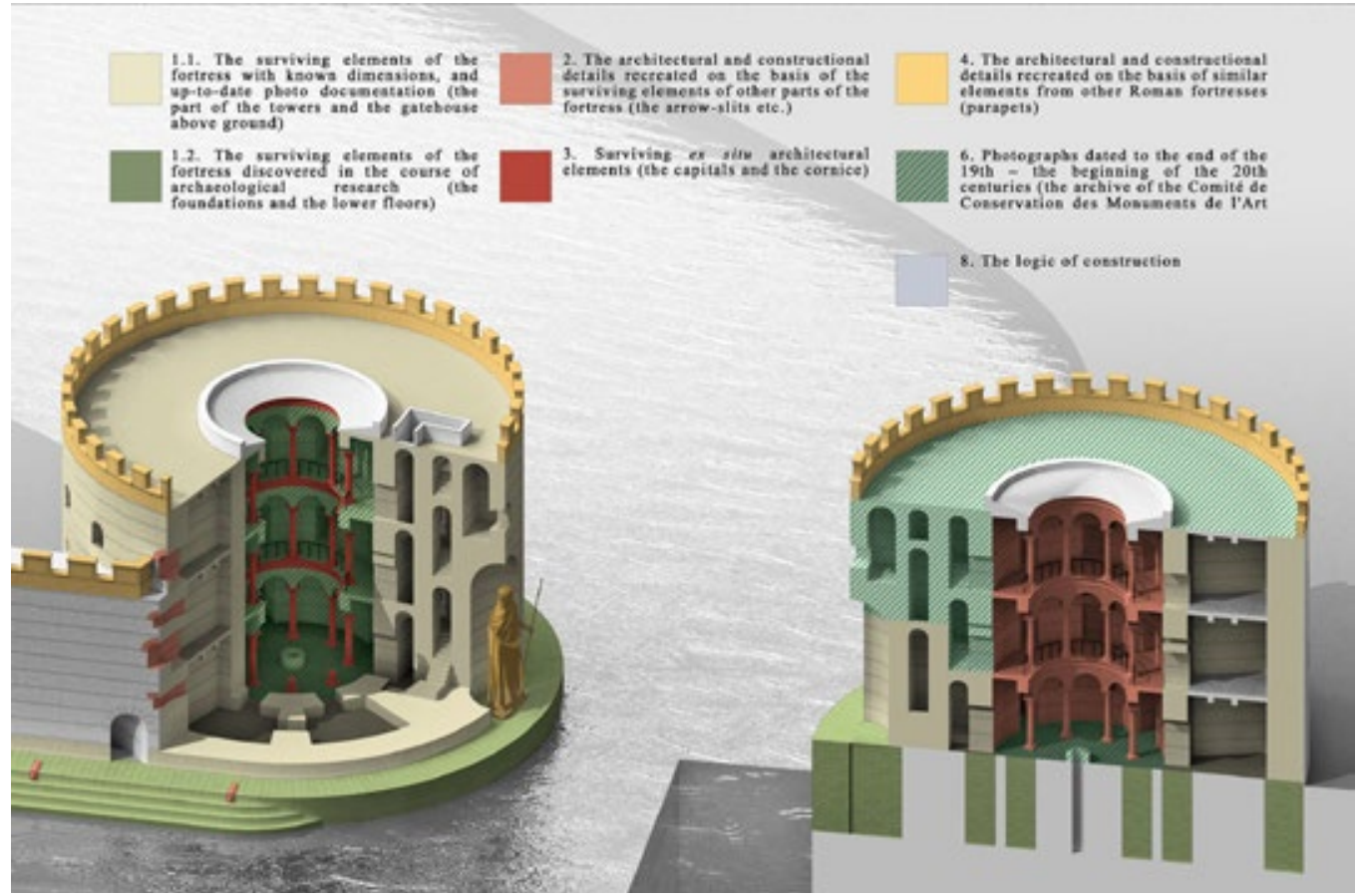

III. 26. Round towers of the fortress of Babylon. Axonometric view. 3D-modelling reconstructive conjecture uncertainty map. Late $3^{\text {rd }}$ - early $4^{\text {th }}$ century. Reconstruction by Dmitry Karelin, Peter Sheehan, Maria Karelina and Tatiana Zhitpeleva

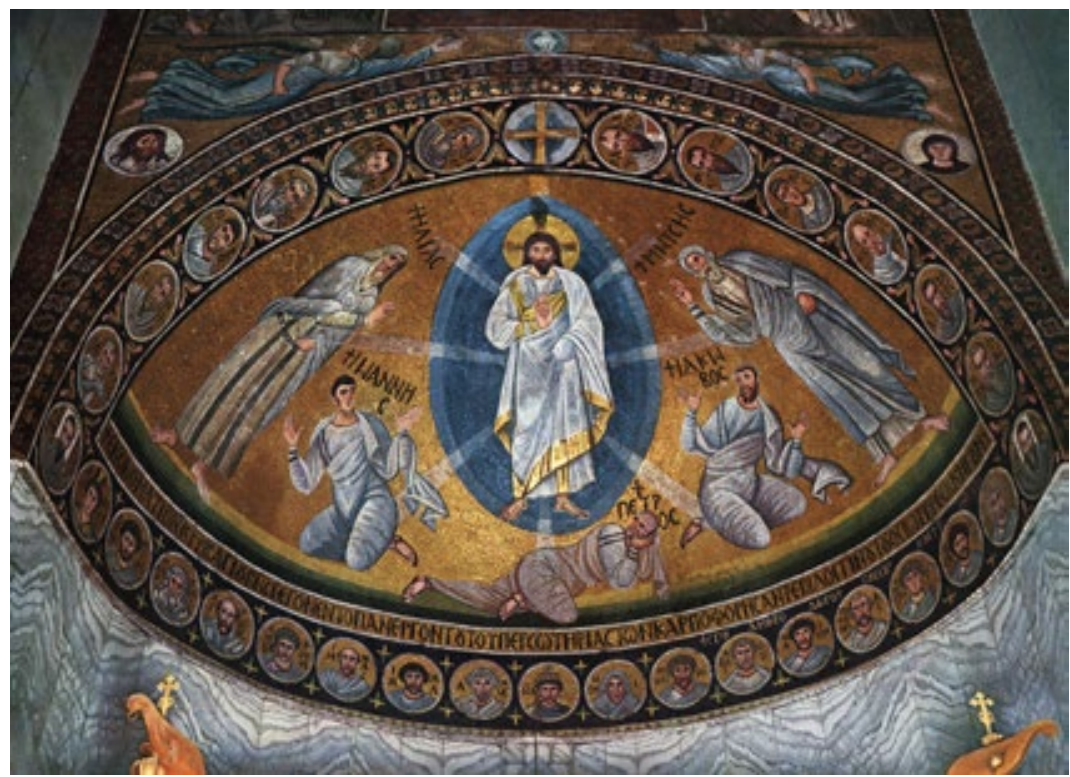

III. 27. Transfiguration in the apse. Church of Saint Catherine on Mount Sinai. Photo by Fanny Vitto 


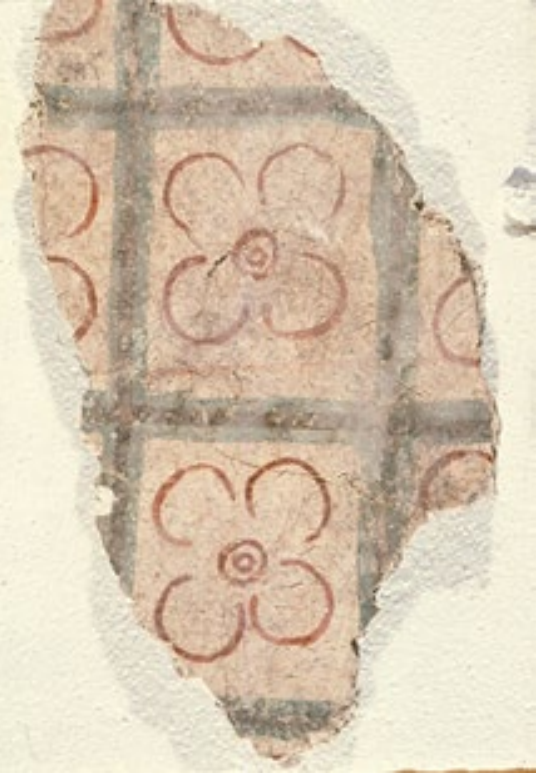

III. 28. Imitation of a coffered ceiling. Synagogue of Rehov. Excavation and photo by Fanny Vitto

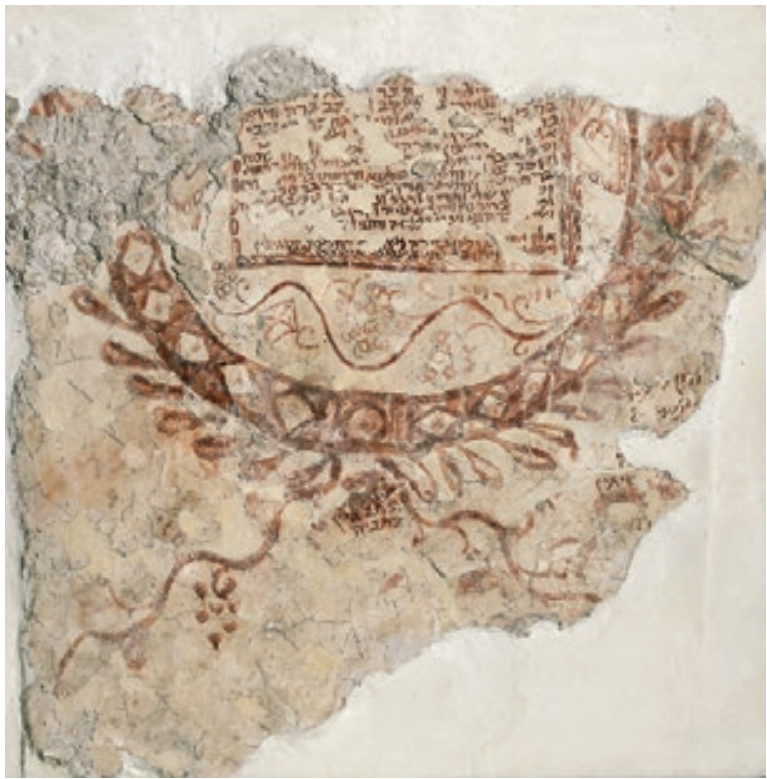

III. 29. Dedicatory inscription. Synagogue of Rehov. Excavation and photo by Fanny Vitto

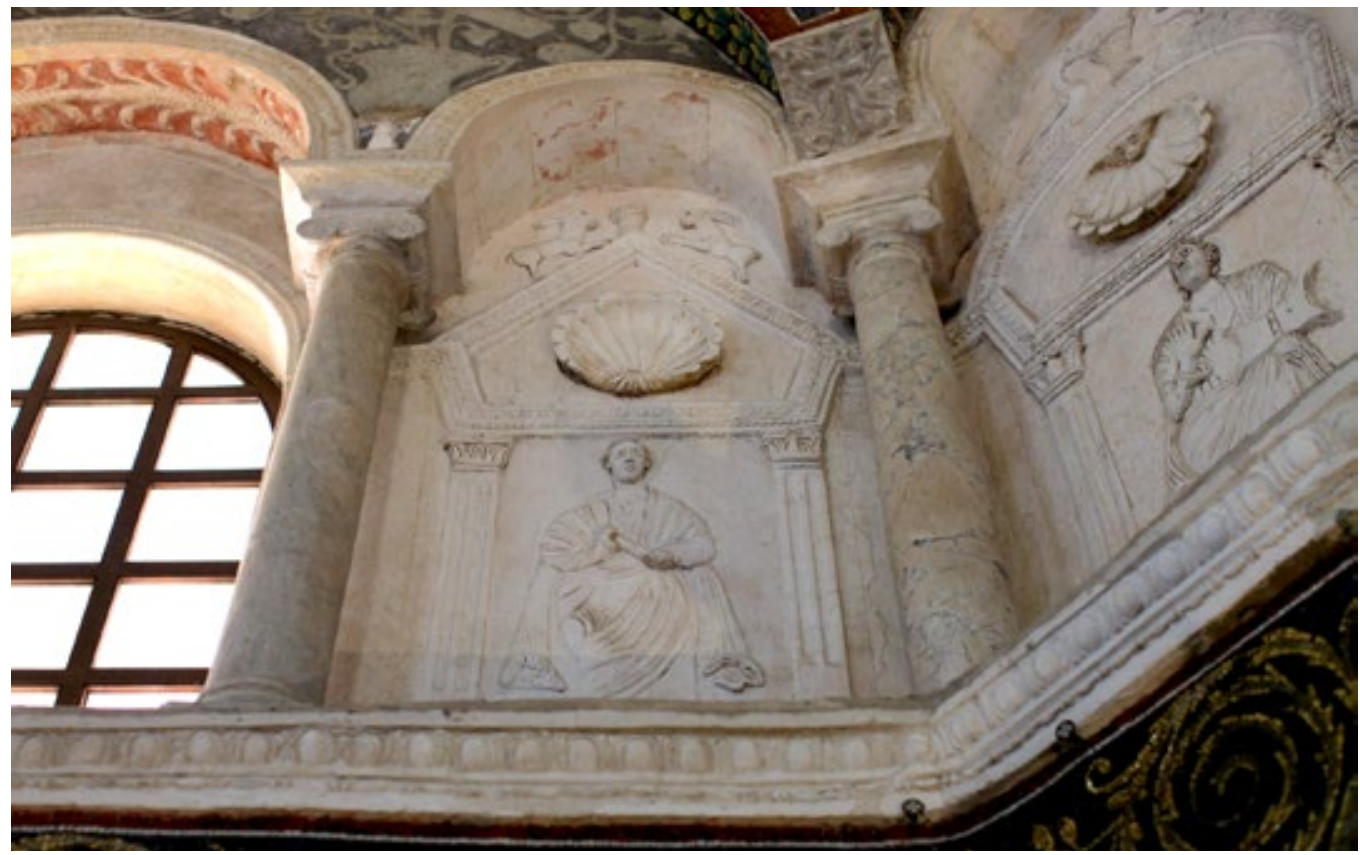

Илл. 30. Баптистерий Православных в Равенне. Ветхозаветные пророки. V в. Стукко. Равенна. Фото Е. В. Рикоты 